\title{
Correction to: Myocardial T1 mapping and extracellular volume quantification: an overview of technical and biological confounders
}

\author{
Stefan K. Piechnik ${ }^{1}$. Michael Jerosch-Herold ${ }^{2}$ (D) \\ Published online: 9 March 2018 \\ (c) The Author(s) 2018. This article is an open access publication

\section{Correction to: \\ The International Journal of Cardiovascular Imaging (2018) 34:3-14 \\ https://doi.org/10.1007/s10554-017-1235-7}

The article "Myocardial T1 mapping and extracellular volume quantification: an overview of technical and biological confounders", written by "Stefan K. Piechnik and Michael Jerosch-Herold", was originally published Online First without open access. After publication in volume 34, issue 1, page $3-14$, the author decided to opt for Open Choice and to make the article an open access publication. Therefore, the copyright of the article has been changed to $\odot$ The Author(s) 2018 and the article is forthwith distributed under the terms of the Creative Commons Attribution 4.0 International
License (http://creativecommons.org/licenses/by/4.0/), which permits use, duplication, adaptation, distribution and reproduction in any medium or format, as long as you give appropriate credit to the original author(s) and the source, provide a link to the Creative Commons license, and indicate if changes were made.

Open Access This article is distributed under the terms of the Creative Commons Attribution 4.0 International License (http://creativeco mmons.org/licenses/by/4.0/), which permits unrestricted use, distribution, and reproduction in any medium, provided you give appropriate credit to the original author(s) and the source, provide a link to the Creative Commons license, and indicate if changes were made.
The original article can be found online at https://doi.org/10.1007/ s10554-017-1235-7.

\section{Michael Jerosch-Herold}

mjerosch-herold@bwh.harvard.edu

1 Oxford Centre for Clinical Magnetic Resonance Research, Division of Cardiovascular Medicine, Radcliffe Department of Medicine, University of Oxford, John Radcliffe Hospital, Oxford OX39DU, UK

2 Brigham and Women's Hospital, and Harvard Medical School, 15 Francis Street, Boston, MA 02115, USA 